PART 8

Endpiece 
Andrew Pettegree - 9789004362871

Downloaded from Brill.com04/26/2023 12:43:53PM via free access 


\title{
Was there an Enlightenment Culture of News?
}

\author{
Andrew Pettegree
}

Friday 28 November 1721 was to be a busy news day in Paris, for now, at last, the notorious thief Cartouche was to be put to death. Cartouche was the Parisian equivalent of London's Jonathan Wild, the leader of a notorious criminal gang. Now, along with several hundred of his confederates, he had been arrested, and after several weeks of interrogation and trial he was to die. Paris had been consumed by all things Cartouche for several months, including an opportunistic musical comedy, Cartouche: the Thieves. The enterprising players had made their way into the prison to interview the gangmaster, who had gallantly assisted their research by teaching them to sing and dance like criminals. Cartouche earned high marks for his bravado and sang froid, for his fate was certain and he was to die one of the cruelest deaths available in the pre-modern judicial system: broken on the wheel, each limb shattered by two blows of an iron bar before he was exhibited, still alive, to the baying crowd. "A bad quarter hour passes quickly", was Cartouche's reported laconic reflection on this grisly fate. This memorable phrase was remembered eighty years later, in a French revolutionary debate on the reform of the penal code; such is the power of celebrity. ${ }^{1}$

Trial, condemnation and subsequent attempts to force Cartouche to name accomplices filled the pages of Paris's diarists, along with details of his last meals; meanwhile crowds packed the Place de la Grève so as not to miss the dramatic denouement. Even after the execution Cartouche fever took some time to subside. The Duchesse d'Orleans, mother of the Regent, fully shared the popular enthusiasm for every last detail: "I ran into the comte d'Hoïm and the chevalier de Schaub. They told me about Cartouche's having been executed yesterday; this detained me quite a while". On 29 November Caumartin de Boissy informed his sister, "For several days, no one has spoken of anything but Cartouche".2

This was the news world of Enlightenment France. Then, as now, investigation of news culture can cast a bleak light on human nature. Certainly in the

1 Paul Friedland, Seeing Justice Done: The Age of Spectacular Capital Punishment in France

(Oxford: Oxford University Press, 2012), pp. 169-172, 231-232.

2 Ibid., p. 171.

(C) ANDREW PETTEGREE, 2018 | DOI 10.1163/9789004362871_016

This is an open access chapter distributed under the terms of the prevailing CC-BY-NC-ND_License 20789004362871 
rumbustious glee with which citizens thronged the place of execution, or the better sort schemed for the best balcony view, we can see little of the rationality, the seriousness of purpose or heightened sensibility that is said to have characterised the Enlightenment. The fascination with executions did have its contemporary critics. As early as 1669 Louis XIV had rebuked several ladies of the court for the morbid eagerness with which they had followed the last suffering of another celebrity criminal, Madame Ticquet, the wife of a magistrate of the Parlement of Paris condemned for having hired men to murder her husband. ${ }^{3}$ And forty years after the execution of Cartouche, Voltaire would further enhance his reputation with a passionate denunciation of the judicial lynching of the Huguenot merchant Jean Calas, done to death after the family had unwisely attempted to cover up the apparent suicide of Calas's son. In 1764, after publication of Voltaire's celebrated pamphlet, Calas would be declared innocent of the crime of his son's murder, of which he had been convicted by the justices of Toulouse in an atmosphere of religious hysteria. The campaign did much to burnish Voltaire's reputation, though of course it could not help the unfortunate Calas, done to death by the same agonising process that had despatched Cartouche.

There was nothing particular to the eighteenth century in the excitement and public curiosity that accompanied the execution of Cartouche and Calas: similar scenes could have been reported in many parts of Europe throughout the period of spectacular public justice. An execution was self-consciously an occasion when the community came together to witness the ceremonial expulsion of individuals who had offended the accepted canons of behaviour, and by their public witness signal agreement with exemplary punishment. If the eighteenth century is different it is largely because we are better informed through the survival of more copious quantities of documentation, and the development of a more extensive network of reporting mechanisms.

This was the age when the development of a fully articulated network of public news media reached its first climax. For three centuries, from the beginning of the sixteenth century onwards, European societies had witnessed the growth of a dense network of interlocking mechanisms for the dissemination of news - a network made possible by the invention of new forms of printed media, though by no means exclusively so. Gossip, correspondence and word of mouth continued to play a major role in vivid news events such as the death of Cartouche, but in the eighteenth century print was becoming the increasingly common means of sating the appetite for news. The newspapers, a form of serial news developed from the early seventeenth century onwards, now

3 Ibid., p. 156. 
reached into every part of Europe. More of Europe's citizens than ever before could now have access to their weekly or even daily fix of news.

This prompts the essential question: was there an Enlightenment culture of news? Was there anything specific to the news culture of the eighteenth century public sphere that reflected the spirit of the Enlightenment? ${ }^{4}$ Here the evidence thus far adduced is distinctly ambiguous. On the one hand, locations where newspapers were perused, such as the coffeehouse or salon, loom large in considerations of the Enlightenment public sphere. The coffeehouse in particular has taken on an almost emblematic role as a place of news gathering, exchange and opinion forming. ${ }^{5}$ Coffeehouses were certainly popular and fashionable. By the mid eighteenth century many of Europe's towns and cities offered a dense network catering to different sociability groups and clientele of different political allegiances. This segmentation, of course, somewhat impeded their effectiveness as locations of political exchange, or at least of rational Enlightenment discourse. In eighteenth-century London, Whig and Tory coffee shops were sharply differentiated, and this was predominantly male space. The salon gave more room for female agency, but catered only to a socially exclusive clientele: the segment of society whose correspondence offers us a window on the latest fashion and the most recent society execution (sometimes, disconcertingly, on the same page).

Most of all, this concentration on location has resulted in far less attention being paid to the structure and actual contents of the newspaper. Newspapers were certainly present in the coffeehouses, but do they function effectively as agents of rational discourse? Can an examination of the newspapers reveal the spirit of the Enlightenment at work? In the pages that follow, this question will be approached though two main lines of enquiry. We will see, firstly, as we trace the origins of the public news media, that many of the features seen as characteristic of eighteenth-century public discourse were essentially present in the developing information culture of preceding centuries. The sixteenth and seventeenth centuries developed both a highly sophisticated multi-media news world and a clear code of news ethics. In the eighteenth century, newspapers certainly took a step forward in terms of availability, but at some cost to the ethical principles established in this earlier age. It becomes increasingly

4 See here, Hans-Jürgen Lüsebrink and Jeremy D. Popkin (eds.), Enlightenment, Revolution, and the Periodical Press (Oxford: Voltaire Foundation, 2004). Jeremy D. Popkin, News and Politics in the Age of Revolution:Jean Luzac's Gazette de Leyde (Ithaca: Cornell University Press, 1989).

5 Brian Cowan, The Social Life of Coffee: The Emergence of the British Coffeehouse (New Haven: Yale University Press, 2005). 
difficult to discern the spirit of the Enlightenment in the rumbustious news culture of eighteenth-century Europe.

\section{The Invention of News}

The instinct for news - to be in the know - is as old as society itself. Some of the oldest surviving written communications bear evidence of this human curiosity and fascination for events both near and far. ${ }^{6}$ But it was only really in the sixteenth century that the provision of news for public consumption could for the first time be efficiently organised on a commercial basis. This was one of the many consequences of the invention of printing in the fifteenth century, though it was only in the sixteenth, from about $15^{20}$ onwards, that print began to make a substantial impact on the developing mechanisms of news exchange. Until this point a functioning news network had essentially been the exclusive preserve of Europe's elites, international merchants, princes and churchmen. Now, through the agency of print, and especially cheap print, news could be shared with radiating circles of new readers.

It had been the Protestant Reformation, Luther's assault on the church in the 1520s, that had first unlocked for Europe's print industry professions the full commercial potential of current events. ${ }^{7}$ As the pamphlet storm of the Reformation receded, German publishers naturally looked for new ways to retain the readers tempted into a habit of book buying by the drama of Luther's protest. This spawned what was essentially a new genre: the short pamphlet of eight or sixteen pages devoted to contemporary affairs. In the course of the sixteenth century, news pamphlets proliferated, though within a relatively narrow thematic range. They brought to Europe's citizens mostly news of the doings of the great: royal entries, treaties and alliances; battles, sieges and the conduct of war. Occasionally they delved into more parochial matters, with accounts of crime or natural disasters. The more spectacular of these events also generated a market for news broadsheets: single sheets devoted to a single event, accompanied by a vivid illustration. Naturally the broadsheets concentrated on events that would most obviously benefit from the inclusion of an illustration. The collections that survive furnish examples of broadsheets dealing with

6 Andrew Pettegree, The Invention of News: How the World Came to Know about Itself (London: Yale University Press, 2014).

7 Mark U. Edwards, Print, Propaganda and Martin Luther (Berkeley: University of California Press, 1994). Andrew Pettegree, Brand Luther: 1517, Printing and the Making of the Reformation (New York: Penguin, 2015). 
floods, earthquakes and notorious crimes, as well as what were known in the unforgiving terminology of the time as 'monstrous births', deformed human or animal births, or conjoined twins. ${ }^{8}$ By far the greatest number, at least judging by surviving examples, recorded strange celestial apparitions: comets or meteors, the Aurora Borealis (the Northern Lights) or instances that have no obvious scientific cognate, such as animals or contending armies in the sky.

All of these news prints, whether in broadsheet or pamphlet form, were strongly moralistic in tone. Tales of exemplary punishment for terrible crimes served an obvious purpose, while heavenly apparitions were universally regarded as portending great or terrible events. Crucial to the form and purpose of news pamphlets was the fact that they were almost inevitably written after the conclusion of the events they described: when a battle was decided, a siege concluded, or a treaty signed. This allowed their authors to write with the benefit of hindsight, when the consequence of an event was known. It also allowed the author to place the event in a wide context: to explain the background and offer analysis.

These early new prints were far from objective. Publishers were very wary of issuing anything that might give offence to their readers, or, perhaps more pertinently, the local authorities. They tended therefore to celebrate exclusively the victories and triumphs of the ruling power, or, in the age of confessional conflict, states of a similar religious persuasion. Reverses and defeats were usually passed over in silence. This obviously posed problems to those who, for professional reasons, required more objective statements of the disposition of military force, and the risks of international commerce. For discerning interested parties of this type, the pamphlets were of little practical use: they relied instead on a parallel manuscript news service offered to customers on a subscription basis.

These avvisi, as they were known, were the greatest news innovation of the age, one that would be deeply influential in the later form of the newspaper. ${ }^{9}$ The avvisi originated, like so many other critical aspects of news culture, in Renaissance Italy. They grew out of the normal practice of merchant correspondence, where the communication of political events likely to shape market conditions was as necessary to successful commerce as details of prices and goods traded. In the sixteenth century, enterprising news agents began to offer such bulletins to subscribing customers on a regular basis, usually weekly.

8 Franz Mauelshagen, Wunderkammer auf Papier: Die 'Wickiana' zwischen Reformation und Volksglaube (Epfendorf: Bibliotheca academica, 2011).

9 Mario Infelise, Prima dei giornali: alle origini della pubblica informazione (secoli XVI-XVII)

(Bari: Laterza, 2002). 
Such services became a recognised part of the news networks first in Rome and Venice, the two established news hubs of the Italian peninsula, before crossing the Alps with the Imperial post service. By the seventeenth century most parts of Europe had their purveyors of manuscript newsletters.

The service was not cheap, but universally recognised as the most reliable form of news available in early modern Europe. Avvisi were also very distinctive in stylistic terms. Again taking their cue from merchant correspondence, they offered their information in short, clipped paragraphs, seldom more than two or three sentences long. ${ }^{10}$ The bare essentials of the pertinent information were generally offered without comment or analysis. It was assumed that the reader would be sufficiently aware of the context to draw their own conclusions.

This was the exact opposite of the pamphlet tradition, and led to an early bifurcation of the European news trade. The avvisi offered regular diets of unembroidered news, with native caution reinforced by an uncomfortable recognition that they were recording unfolding events. It was by no means clear how things would turn out, or even which of their mass of reports would turn out to be significant. The avvisi traded in a regular flow of pure news, offered to an elite audience of those who had a professional need for accurate information. Pamphlets served a far broader market of those who were not regular consumers but whose interest could be piqued by momentous events. These occasional readers welcomed both the detailed narrative and guidance on the significance or likely consequences of what had occurred. These two traditions would continue to exist, largely in parallel, until well into the eighteenth century. It would only be at the very end of the period that the contrasting streams of information and opinion would be fully merged.

Before we pass on to consider these later events in more detail it is important to recognise one other form of news medium, seldom if ever mentioned in studies of the news, and that is state communication. In the early modern period all government regimes functioned to some extent by a process of dialogue and regulation. While court ritual might emphasise the ineffable Godgiven authority of the ruler, in reality all regimes existed to a large extent by consent; and this had to be cultivated and nurtured. Early modern states developed an elaborate infrastructure for making known changes in the law, and this was an age in which the arm of the state encroached into ever expanding areas of civic life.

10 See the splendid examples from the newsletter collection of the Fuggers of Augsburg at http://fuggerzeitungen.univie.ac.at/en. 
Europe's princes were quick to see the potential of print for making known their intentions: to their subjects but also to neighbouring states. These ordinances and proclamations were to a wholly unacknowledged extent both news-bearing and persuasive. ${ }^{11}$ These important documents are only now being systematically studied; they reveal an acute sensitivity to the needs and expectation of the citizenry, and recognition that law requires the consent of key groups among them.

These printed ordinances enhanced, rather than replaced, highly efficient existing mechanisms for the communication of law and regulations. The range of business they cover is extraordinarily broad, from announcements of new taxation, through detailed regulation of commerce, to the announcement of a search for a missing child or notorious criminal. ${ }^{12}$ These, too, have their echo in the seventeenth-century newspaper world. They are a reminder that long before the coffee shop or the Enlightenment salon, Europe's urban communities had an extremely various news world. Indeed, the effectiveness of this news environment created a challenging context for the new periodical news ventures of the seventeenth century.

\section{The First Newspapers}

Just as the thirst for books in the fifteenth century helped inspire the birth of print, so the thirst for news spawned a significant new innovation: the newspaper. The newspaper emerged from the milieu of existing newsmen: the first man to attempt a regular printed serial, Johannes Carolus of Strasbourg, was the proprietor of a manuscript news service. ${ }^{13}$ With his newspaper, rather as with books in the incunabula age, he was essentially mechanising (and thereby increasing the volume) of an already existing part of the communication process. This may help explain why, faced with a clear choice of models, the argumentative pamphlet or the dispassionate manuscript newsletter, the first newspapers opted decisively for the latter. This is a highly significant choice. In the first generations, the newspapers would essentially adopt the style and

\footnotetext{
11 Pettegree, Invention of News, and forthcoming studies by Saskia Limbach and Arthur der Weduwen.

12 Stephen J. Milner, “Fanno Bandire, notificare, et expressamente comandare”. Town Criers and the Information Economy of Renaissance Florence', I Tatti Studies in the Italian Renaissance, 16 (2013), pp. 107-151.

13 Johannes Weber, 'Strassburg 1605. The Origins of the Newspaper in Europe', German History, 24 (2006), pp. 387-412.
} 
structure of the manuscript newsletters. They offered a succession of short, staccato reports from the continent's major news hubs, all presented without comment or explanation. It was assumed that the subscriber would need no further guidance on the meaning or significance of what they were being told.

While this may have been true for those who could afford the expensive manuscript newsletters, it was hardly the case for members of the far wider circle who must be persuaded to subscribe if the newspapers were to succeed. Given that a year's subscription to a manuscript newsletter might cost the equivalent of $£ 10$ or more, a dozen subscribing customers would provide a decent living. But a newspaper subscription was governed by the normal economics of print. An eight-page newspaper in pamphlet form would retail for as little as two pence. It was hard to turn a profit even on a print run of three or four hundred. For this reason the early years of the newspaper were characterised by commercial difficulties similar to those that had afflicted the fifteenthcentury print industry, once the first technological fascination had worn off.

The establishment of the first newspaper in Strasbourg (then in the Holy Roman Empire, rather than France) was symbolic in one further respect: it marked the shift in the axis of the news market from southern to northern Europe. In the sixteenth century the Italian peninsula had been the undisputed heart of the European news world. Now, with the birth of the newspaper, primacy shifted decisively to Germany, the Netherlands and England. Newspaper publication spread most rapidly in the city states and principalities of the Holy Roman Empire. We can enumerate ninety papers published before $165^{\circ}$ in the German-speaking lands, in at least thirty different cities. Given that it was highly unusual for a city to be able to sustain two competing papers, we can deduce that many of these titles were very short-lived: in fact, for many newspapers we know of their existence from just one surviving issue. ${ }^{14}$ Those newspapers that endured were often sustained by direct subsidy from the local prince: hence the rather scathing designation as 'court papers'.

The first truly commercial market was that established in the booming and heavily urbanised Dutch Republic. A new state, with a buoyant economy and apparently limitless entrepreneurial energy, the Dutch Republic, and especially its largest city Amsterdam, took to the newspaper with great enthusiasm. Amsterdam had two weekly newspapers by 1618 , and for a brief period in the 1640 s as many as seven. ${ }^{15}$ In England the innate caution of the Stuart monarchy initially restricted the opportunities for news serials, and as late as 1632 they

14 Jan Hillgärtner, German Newspapers, 1605-1650: A Bibliography (Leiden: Brill, 2019).

15 Arthur der Weduwen, Dutch and Flemish Newspapers of the Seventeenth Century, 1618-1700 (Leiden: Brill, 2017). 
were banned altogether. This period of official restraint was temporarily ended by the turbulence of the Civil War, which provoked a rash of new serials. Few lasted more than a few months, though the most successful on the royalist and Parliamentarian side were regarded as influential tools in the struggle for moral supremacy. The victorious Commonwealth quickly tired of an unregulated free-for-all, introducing restrictions continued by the restored monarchy. It was only in the last decades of the century that a truly free, multi-title market was introduced in London. England would enter the eighteenth century with far and away the most vibrant and commercially mature newspaper market, a mass of competing titles serving a segmented and diverse market.

Elsewhere, the picture was more mixed. Italy had not taken to the newspapers. Neither Rome nor Venice had a successful newspaper during the seventeenth century, and the earliest ventures, which date from the 1640 , all appeared in secondary population centres. ${ }^{16}$ These papers scarcely flourished. All were quasi-official ventures, closely monitored or even directly published by the court. The conspicuous failure of the newspapers in Italy partially reflects continued satisfaction with the more confidential medium of the manuscript news books. It also signals the declining importance of the Italian states in European affairs.

The rising power of France, with its twenty million inhabitants, at first sight represents a far more promising terrain for newspapers. But here the government chose a different path, establishing a single title, the Paris Gazette, as a monopoly provider. ${ }^{17}$ The Gazette monopoly was carefully policed. To avoid the establishment of competitors, the shrewd proprietors (the family Renaudot, who ran the paper for the best part of 150 years) franchised a series of provincial reprints; in the closely controlled Paris market there was no possibility of a rival. The news coverage of the Gazette was good, since the Renaudot were provided with access to a good deal of official diplomatic correspondence. The paper was unusual also in the attention it devoted to domestic news, or at least to the doings of the king and court. Here its coverage was unrelentingly fawning and obsequious.

The editorial submissiveness of the Paris Gazette has been much deplored by newspaper historians, as it was by contemporary commentators, but seventeenth-century newspapers throughout Europe were generally inclined to caution in their coverage of domestic events. Most newspapers devoted

\footnotetext{
16 Nina Lamal, Late with the news: Italian Engagement with Serial News Publications in the Seventeenth Century (1639-170o) (Leiden: Brill, 2019).

17 Gilles Feyel, L'annonce et la nouvelle: La presse d'information en France sous l'Ancien Régime (1630-1788) (Oxford: Voltaire Foundation, 200o).
} 
eighty percent or more of their space to foreign despatches. Coverage of events nearer home seldom extended beyond the relatively safe terrain of ships safely arrived in port or the movements of the Prince. With the exception of the more contentious English press, domestic politics were generally regarded as being off limits.

Most German papers had only a limited local circulation, were closely associated with the local court and were often dependent for their survival on a direct financial subsidy. Even in the Netherlands, where the papers came closest to true independence through their early adoption of paid advertising, the exuberance of the early decades was progressively reined in. The Dutch Republic ended the seventeenth century with a good range of newspapers, but now distributed one to a city: in Amsterdam, Haarlem, The Hague and Leiden. The proprietor of each paid a substantial fee to the local municipality for the right to make large profits, a privilege that could easily be withdrawn or reassigned if the paper caused offence. Thus in most parts of Europe government authorities found ways of enforcing the dutiful obsequiousness so evident in the Paris Gazette. If less obvious, and certainly less florid, elsewhere, newspaper proprietors usually had a clear idea of the limitations of their freedom of action.

\section{Journalism}

In these multiple ways, journalist freedom of action was extremely constrained: not only because of the obvious danger of punitive repercussions should a paper step out of line, but because the economics of publication were so daunting. The cover price of a paper could seldom cover the costs of news-gathering and production. Any theoretical profit margin was easily eroded by the difficulty of collecting subscriptions. Many papers published in the seventeenth century were the work of a single proprietor, working without further editorial staff. The proprietor would create the text by the relatively simple process of digesting incoming reports, many taken either verbatim from manuscript avvisi or from other newspapers.

This digest had to be crammed into a four- or eight-page pamphlet, or, in the Dutch case, a single half-sheet printed on both sides. The inflexibility of the form, and the fixed date of publication, was particularly restrictive when major news events occurred; at such times a swiftly composed pamphlet would still trump a newspaper. Proprietors were aware of this danger, and would sometimes publish an extra issue (an 'extraordinary') to reward the loyalty of subscribers; but in normal circumstances a single issue seldom comprised more 
than about two thousand words..$^{18}$ As the century wore on the most successful papers, particularly in the Dutch Republic, developed a more extensive range of correspondents, responsible for collecting news and forwarding it to the editorial office. Some Dutch papers of the 168 os list as many as twenty-five places of correspondence. ${ }^{19}$ But they were extremely reluctant to add extra pages, preferring to cram more news into the same double-sided sheet.

In many ways the newspaper proved to be a remarkably conservative and inflexible medium: cautious in the choice of material, typographically unadventurous, an unchanging recitation of bare reports from Italy, Germany and France. And some things could not be changed even by the most adventurous newsmen, notably the speed at which news could be obtained. Europe's postal network was substantially in place before the foundation of the first newspapers, and reached its refined state within the next thirty years. Thereafter the speed at which news passed through the postal routes was not significantly improved until the middle of the nineteenth century, with the advent of steampowered ships, the railways and the telegraph. ${ }^{20}$ In these critical elements of infrastructure, the Enlightenment newspaper was not significantly different from its seventeenth-century predecessors.

Harassed and living on a financial knife-edge, Europe's newspapermen were nevertheless thoughtful about their trade. However difficult it might be to obtain reliable news, newspapermen cared deeply that what appeared in their issues was true. They hesitated to report rumour as fact, and if a report were uncorroborated they would indicate as much. An uncertain source was frequently labelled as such: 'we hear from Vienna'; 'it is said that in Lyon'. If news confidently reported turned out to be false, many newspapermen felt the need, albeit often with an ill grace, to offer a correction in the next issue. ${ }^{21}$

Here we see the beginnings of a code of journalistic ethics: not always clearly articulated, but nevertheless strongly felt. ${ }^{22}$ This consisted of several elements: the concern that news should be true and verifiable, hence the need for corroboration; the suspicion of opinion, and the continued sense that a reader should be presented with the facts, having sufficient wit to draw their

18 For examples of these special issues, see Der Weduwen, Dutch and Flemish Newspapers.

19 Ibid.

20 Joop K. Koopmans, 'Supply and Speed of Foreign News to the Netherlands during the Eighteenth Century. A Comparison of Newspapers in Haarlem and Groningen', in his News and Politics in Early Modern Europe (1500-180o) (Leuven: Peeters, 2005), pp. 185-202.

21 Pettegree, Invention of News.

22 Stephen J.A. Ward, The Invention of Journalism Ethics: The Path to Objectivity and Beyond (Montreal: McGill University Press, 2004). 
own conclusions. This was famously set out in the editor's address to his readers in the first issue of the Daily Courant, where he swore off any commentary or conjectures of his own, "supposing other people to have sense enough to make reflections for themselves". 23

These considerations in turn gave birth to a sense that the proper role of the newspapers was to remain impartial: to present facts for the judgement of the reader. In places like London with competing newspapers and fractious politics, such a position was impossible to maintain, but this was very much the exception. Most newspapers were published in places where there was no local competitor, so it was a matter of simple prudence not to risk offending one portion of your readership. This principle was enunciated with characteristic elegance by Benjamin Franklin, a newspaperman in his early career before he became a leading statesman of the American colonies. "Printers are educated in the belief", he wrote, "that when men differ in opinion, both sides ought equally to have the advantage of being heard by the public". ${ }^{24}$

Such a principle might seem ideally suited to the age of Enlightenment: the newspaper as the facilitator of rational discourse, presenting educated readers with the facts to shape their views. In fact, as the eighteenth century wore on, these principles came under increasing strain as contentious politics put pressure on the ethical principles adduced in the early newspapers. The importation of the spirit of the pamphlet, argumentative and partisan, threatened to effect the first fundamental change in the form and style of the newspaper since their introduction. Not all would agree that this was a change for the better.

\section{Bought and Sold}

There is no doubt that the eighteenth century witnessed a considerable growth in the periodical press. By 1750 there were more than go newspapers published in German-speaking Europe, and 150 by 1785 ; although most were still small local ventures, the total print run was something approaching 300,000 copies. While the Gazette maintained its monopoly in France, the appetite for news can be gauged by the fact that by 1749 no fewer than 28 cities were served by authorised reprints. ${ }^{25}$ In England the efflorescence of the London press was now echoed by a strong growth in the provincial news market; an echo in a very real

\footnotetext{
23 Daily Courant, 11 March 1702. Pettegree, Invention of News, p. 247.

24 Quoted in Pettegree, Invention of News, p. 335.

25 Popkin, News and Politics, p. 2.
} 
sense, as much of the text of these newspapers was extracted directly from the London papers. ${ }^{26}$ The same can be said of the first papers in colonial America. These early colonial papers, generally distributed one to a colony, drew up to $70 \%$ of their copy from newsletters and papers brought over on the Atlantic packages. ${ }^{27}$ Not surprisingly, many early newspaper publishers doubled as the local postmaster, who in this way were able to monetise their privileged early access to the incoming mails.

There is little doubt of the appetite for news. Whether the expanded newspaper trade would be able to satisfy it was more questionable. The German papers by and large maintained the traditions of their seventeenth-century predecessors, eschewing local politics, and this was also the settled practice of the Dutch papers, now monopoly providers in their own local markets. This studied neutrality came under increasing strain during the Patriot agitation of the 1780 s, but it was not given up without a struggle; witness the pained editorial placed in the Leidse Courant of 1785 :

Since a newspaper is meant to publish news events, and print official documents, and is not designed to be a collection of contesting articles, we kindly request our contributors not to bother us with this kind of copy. ${ }^{28}$

Like Canute holding back the tide, this venerable tradition was about to fall victim to revolutionary pressures, in the Netherlands as elsewhere, but it does signal one significant shift in content in the eighteenth century, as the short clipped reports of the early papers were increasingly interspersed with long official documents, published complete or in extended extracts. This was the expression of a public service obligation that many newspaper proprietors were happy to honour, but it did not make for lively reading. The continued absence of a strong editorial line made the newspapers increasingly vulnerable to the competition of the new political monthlies or essays published in serial form. Even the satirical Spectator genre, while ostensibly denying any political intent, often contained more pointed political comment than the newspapers.

The general exception, of course, is England, with its lively and partisan press. Here, for the first time, a newspaper culture entered wholeheartedly into the hurly burly of domestic politics. But this was not because sales or advertising

26 Roy MacKeen Wiles, Freshest Advices: Early Provincial Newspapers in England (Columbus: Ohio State University Press, 1965).

27 Richard D. Brown, Knowledge is Power: The Diffusion of Information in Early America, 17001865 (New York: Oxford University Press, 1989).

28 Pettegree, Invention of News, p. 358. 
revenue had given the newspapers the independence of financial security: rather, in practice, almost all London papers were bought instruments of either government or opposition. It was in this context that the term journalist entered the English language, not as a description of an honoured profession, but as a term of abuse. A journalist was seldom employed by a single paper, but retained by the government (or an opposition politician) to place articles as required in one or other of their paid agents' publications. Most of England's leading writers, including Samuel Johnson, accepted fees for this sort of work, but a more characteristic figure was probably a Mr Taylor, who was paid £10o for writing in various government-supporting papers in $1791 .{ }^{29}$ We know of him only because of this entry in Pitt's secret service accounts. Otherwise he makes no impact on the record. In Walpole's day, payments had generally gone directly to the newspaper publisher, for both printing and writing the paper: copies could then be disbursed free of charge to a friendly audience.

The result was that the London press earned a reputation for vicious partisanship that even our modern day press would find hard to match. No reputations were spared, not even the royal family. In the last decades of the eighteenth century, the London press found new ways to aggravate the leaders of society, and line their pockets, by mixing political abuse with salacious stories about their private lives. The model in this brave new world was the Morning Post, a lively venture established in London's West End. From the beginning it assumed that readers wished to be entertained as much as informed. Its runaway success inspired many imitators. The system was called selling paragraphs. A paper would obtain a story about the antics of a society figure or member of the aristocracy. The victim would then be offered the opportunity to suppress the story in return for a fee. Should the publication go ahead, there was the further opportunity to place a rebuttal, again in return for a fee. This was a conscienceless trade, but the practice became endemic: a reminder that long use and familiarity can make the appalling commonplace. A rare hold-out like William Cobbett believed that his failure as a newspaper editor could be attributed to his refusal to sell paragraphs. The descent into scandal and titillation completed the degeneration of the newspaper ideal in eighteenth century London.

In France the Gazette sailed on, secure in possession of its privileged monopoly. This did not spare France increasingly rancorous political debate, not least a titanic mid-century struggle between the ministry and the Parlement of Paris. Reverses overseas also unleashed a torrent of criticism, unreported in the 
Gazette (as were the military setbacks). ${ }^{30}$ The Gazette's very traditional interpretation of a newspaper's duty, as an obedient instrument of royal power, created an opportunity eagerly seized by a group of French-language newspapers published abroad, most notably the celebrated Gazette de Leyde. Sober, serious, measured and well-informed, the Gazette de Leyde was extensively read outside the French-speaking world, and built a towering reputation. By the middle of the seventeenth century it was Europe's de facto newspaper of record.

Not surprisingly both the Gazette de Leyde and its sober-sided editor, Jean Luzac, have attracted a great deal of admiring comment from modern scholars. ${ }^{31}$ In many respects this was the quintessential Enlightenment newspaper, serious and painstaking. Luzac refused any hint of subsidy from those seeking to influence the choice of contents and certainly never descended to the ribald abuse practiced in the London press. The Gazette de Leyde was certainly a remarkable creation, frequently praised in diplomatic and intellectual circles. Its influence, however, was probably more circumscribed than we may be led to believe by this chorus of approbation. The Gazette de Leyde could only circulate in France with the connivance of ministers, who could, had they chosen, simply have instructed the postmaster to refuse consignments. Luzac was well aware of this, and tailored his coverage of French political events accordingly. The French authorities were generally happy to allow the circulation of foreign newspapers so long as they maintained this measured coverage of French events; they recognised that publication outside France offered an assurance of editorial independence that was not always justified. The Courrier de l'Europe, published in London, was sustained by a direct subsidy from the French government. ${ }^{32}$

The print run of the Gazette de Leyde was not especially large, and not all the copies were delivered to France. Its circulation was a fraction of that of the apparently despised Paris Gazette. We must not assume that because we admire the judicious reporting of Luzac from Leiden, this is necessarily what French citizens were themselves looking for to assuage their hunger for news. We get some hint of their news priorities in the carefully assembled Paris police reports, a wonderful source that offer us a sort of equivalent to the reports of the Mass Information project set up to monitor civilian morale in Britain during

30 Tabatha Ewing, 'Invasion of Lorient: Rumor, Public Opinion and Foreign Politics in 1740s Paris', in Charles Walton (ed.), Into Print: Limits and Legacies of the Enlightenment (University Park, PA: Pennsylvania State University Press, 2011), pp. 101-112.

31 Popkin, News and Politics.

32 Ibid., p. 54. 
the Second World War. ${ }^{33}$ The Paris police files report that café goers followed the royal sex life with obsessive interest, with sympathy or disfavour depending largely on the general climate of politics. The French crown had deliberately placed itself at the centre of eighteenth-century celebrity culture, and this was the price.

A further revealing insight into the news culture of the Ancien Régime comes from Pierre Manuel, writing from the perspective of the new revolutionary freedoms after 1789. Manuel was savage about the Gazette:

A people that wants to be informed cannot be satisfied with the Gazette de France. Why should it care if the king has performed the ritual of footwashing for some poor folk whose feet weren't even dirty? Or if the queen celebrated Easter in company with the comte d'Artois? Or if Monsieur deigned to accept the dedication of a book that he may never read?

A fair point, but what did the people want: serious discourse on economic affairs? An analysis of battlefield tactics? Not at all:

The people want to know everything that is actually done and said in the court - why and for whom the cardinal de Rohan should have taken it into his head to play games with a pearl necklace; if it is true that the comtesse Diane appoints the generals of the army and the comtesse Jule the bishops; how many Saint Louis medals the minister of war allotted to his mistress for distribution as New Year's presents. ${ }^{34}$

It was not the triviality of the Gazette that offended, rather that it provided the wrong sort of gossip. According to Manuel the political beau monde wanted something far closer to the irreverent London scandal sheets. For this they had to turn to the manuscript nouvelles à la main, now largely shorn of their seventeenth-century high-mindedness in a society hungry for scandal.

\section{Revolutions}

The age of revolutions was in some respects the ultimate test of Enlightenment principles of public discourse. To some, merely to throw off the constraints

33 Robert Darnton, 'An Early Information Society: News and the Media in EighteenthCentury Paris', American Historical Review, 105 (2000), pp. 1-35.

34 Darnton, 'Early Information Society', p. 6. 
that hampered the free expression of opinion was a sufficient warranty of ultimate victory. As Thomas Paine put it in The Rights of Man, "Ignorance is of a peculiar nature; once dispelled it is impossible to re-establish it. ... It has never yet been discovered how to make a man unknow his knowledge or unthink his thoughts". ${ }^{35}$ Certainly it speaks volumes for the importance attached to news that the issue of press freedom played a crucial role in all the main revolutionary events of the age. The press was, in this sense, both agency and cause.

In England the long and complex agitation unleashed by John Wilkes would eventually bring significant victories for the principle of a free press. Wilkes was not an easy man to follow: volatile, erratic and not particularly scrupulous. But his cheerful heedlessness epitomised a risk-taking spirit that ultimately made the London press impossible to harness within traditional constraints. In the American colonies, too, it was the perceived assault on the freedom of the press, the Stamp Act crisis, that jolted the colonial press out of its tradition of placid impartiality. It was hard not to take sides against a financial imposition that many believed, with some justice, threatened the financial viability of colonial papers. Certainly the logistics of obtaining the stamped paper were far more daunting than in England, where a similar imposition had been absorbed without undue disruption. The new solidarity of political activism, and the swift victory as the Stamp Act was withdrawn, made it more difficult to retreat from the political front when other crises followed in its wake, though the colonial press never again showed the same unity of purposes as it did here, in the defence of its own economic interest. In France the destruction of the hated Gazette monopoly was one of the earliest revolutionary acts, unleashing a flood of news serial publications (and pamphlets) that would chronicle every act of the unfolding drama over the next decade.

Revolutions, of course, are seldom kind to their first begetters; and so it would prove to those who put the freedom of the press at the heart of the revolutionary agenda. In the American colonies the long march to independence left many casualties along the way, not least the hope of free and rational debate. Many colonial newspaper proprietors were men of a naturally conservative disposition, and as postmasters, imperial officials. The violence and disorder of the Boston commotions were to men of this stamp naturally uncongenial. But the gradual polarisation of opinion left little room for equivocation: to be insufficiently warm in the Patriot cause was to become, by default,

35 Quoted in Elizabeth Eisenstein, 'On Revolution and the Printed Word', in Roy Porter and Mikuláš Teick (eds.), Revolution in History (Cambridge: Cambridge University Press, 1986), pp. ${ }^{186-205}$. 
a Tory. ${ }^{36}$ The banner slogan that decorated many newspapers, 'Open to all parties, but influenced by none', was now an empty gesture towards an earlier tradition no longer relevant to the new realities of the revolutionary conflict. Press freedom had in effect been redefined to mean the freedom to support liberty against imperial tyranny. Only in cities occupied by the British army was it safe to offer contrary opinions, with the consequence that publishers who expressed loyalist sentiments were inevitably denounced as paid agents of the London Treasury.

The ironic consequence of this functional redefinition of press freedom the freedom to agree - was that the nearest semblance of open debate on policy towards the colonies was to be found not in America, but in the capital of Imperial tyranny, London. Here a considerable part of the London press continued to press the colonial cause, a drumbeat of criticism courageously maintained despite predictable outrage at a lack of patriotic solidarity. For those determined to pursue what was increasingly clearly an unwinnable war, the steady and remarkably unrestrained interrogation of a critical press was a significant additional burden. ${ }^{37}$

In France, the decade between 1789 and 1799 would spawn over 1,400 serial publications, in Paris alone. ${ }^{38}$ Almost all of the major figures of the revolutionary years were at some point journalists; for some, the periodical that was their mouthpiece was the cornerstone of their claim to a public voice. But in rejecting the sycophantic tone of the Gazette, the papers of revolutionary France gradually came to reject almost every other tenet of journalism as it had developed in the last two centuries. Gone was the sober recitation of news from Europe's capitals: the new periodicals were absorbed by the unfolding dramas at home, a relentless tumult of advocacy and denunciation. Each became the instrument of a leading actor or faction, and many died with their directing spirit, for, as never before, in revolutionary France journalism was a deadly trade. Brissot, Marot, Camille Desmoulins and Hébert (Père Duschesne) all fell victims to the terrors they had unleashed.

36 Stephen Botein, 'Printers and the American Revolution', in Bernard Bailyn and John B. Hench (eds.), The Press and the American Revolution (Worcester: American Antiquarian Society, 1980), pp. 11-57.

37 Andrew O'Shaughnessy, The Men Who Lost America: British Command during the Revolutionary War and the Preservation of the Empire (New Haven: Yale University Press, 2013).

38 Hugh Gough, The Newspaper Press in the French Revolution (London: Routledge, 1988) and 'The French Revolutionary Press', in Hannah Barker and Simon Burrows (eds.), Press, Politics and the Public Sphere in Europe and North America, 1760-1820 (Cambridge: Cambridge University Press, 2002), pp. 182-200. Jeremy D. Popkin, Revolutionary News: The Press in France, 1789-1799 (Durham, NC: Duke University Press, 1990). 
The Revolution also addressed itself to the irrationality of Ancien Régime justice. The theatre of punishment was everything that a philosophe despised: arbitrary and vicious, shot through by custom, rituals and distinctions of status that prescribed a baroque cocktail of differentiated punishments. In 1791 the revolutionary Assembly discussed abolishing the death penalty altogether. The most eloquent advocate of such a cause was the young Maximilian Robespierre:

I come not to beg the Gods, but the legislators who must be the organs and interpreters of eternal laws which divinity has dictated to mankind, to erase from the Code of the French the blood laws which call for judicial murders. ${ }^{39}$

The Assembly drew back from such a radical proposal, instead opting for justice that recognised no variations of status; all would be despatched by the same method, beheading, and by a new painless mechanism, the guillotine. The guillotine was the ultimate rational killing machine, the triumph of Enlightenment thought and science. And it was not immediately popular. The fact that there was so little drama angered onlookers; when the first prisoner was despatched with lightning speed, onlookers expressed their disappointment, chanting 'Give me back my wooden gallows'. Such disappointment was short-lived, for the Paris mob soon learned how to create a sense of occasion as the pace of executions accelerated towards the Great Terror. When Jacques René Hébert, creator of the ribald alter ego Père Duschesne, faced his own appointment with death, 400,00o lined the streets to watch him die, determined that a fallen hero should feel their full wrath. The despatch of so many revolutionary heroes was the signal accomplishment of Maximilian Robespierre, who had by now abandoned both his distaste for capital punishment and his commitment to the freedom of the press. Shortly before concluding his ascent to power, Robespierre had sketched an extraordinary political catechism. This demonstrates the extent to which he now saw unlicensed freedom as the heart of the discord that had engulfed the revolutionary movement:

What is our aim? It is the use of the Constitution for the benefit of the people.

Who is likely to oppose us? The rich and the corrupt.

What methods will they employ? Slander and hypocrisy. 
What factors will encourage the use of such means? The ignorance of the sans-culottes.

The people must therefore be instructed.

What are the obstacles to their enlightenment? The paid journalists who mislead the people every day by shameless distortions.

What conclusion follows? That we ought to proscribe these writers as the most dangerous enemies of the country, and to circulate an abundance of good literature. ${ }^{40}$

On 16 June 1793 he invited the Committee of Public Safety to punish "treacherous journalists who are the most dangerous enemies of liberty". 41

The passing of the revolutionary tide was marked by measures to rein in the press. The post-Thermidor regimes moved swiftly to repress the most offensive titles, creating a legislative context eagerly embraced by Napoleon Bonaparte when he seized power in 1799. Of the eighty Parisian publishing houses chosen to be retained under the Napoleonic system, only nineteen specialised in journals or periodicals. There was no great public outcry. The new restrictions imposed on the press seemed to have accorded with a public desire for a period of respite from the incessant calls to arms.

In the new United States, the frantic tone of press criticism eventually goaded John Adams, faced with the impossible task of following the sainted George Washington, into passing the Sedition Act, criminalising false statements critical of the Federal government. When this was allowed to lapse by the new president, Thomas Jefferson, statesmen of the early Republic would pay a heavy price for the constitutional guarantee of free speech, subjected to a barrage of rancorous abuse that overstepped all restraints of civility.

This was, furthermore, a press largely bought and paid for by interested parties. ${ }^{42}$ It would be technological innovation in the nineteenth century, especially the introduction of the steam press, that would finally place the press on a firm financial footing, and provide the prospect, if not the guarantee, of editorial independence. The nineteenth century would witness far more revolutionary change in the newspaper world than the age of the Enlightenment.

The eighteenth century had demonstrated that the appetite for news continued to run ahead of the supply of newspapers in many parts of Europe, despite

40 Quoted in Ruth Scurr, Fatal Purity: Robespierre and the French Revolution (London: Chatto and Windus, 2006), p. 255.

41 Gough, The Newspaper Press, p. 98.

42 Marcus Daniel, Scandal and Civility: Journalism and the Birth of American Democracy (Oxford: Oxford University Press, 2009). 
steady incremental growth in the quantity and frequency of issues. For much of the period the newspaper world was characterised by a profound conservatism of form and style; the boisterous London press was in this respect the great exception. Serious political debate was obliged to find other avenues: the new political journals, the venerable pamphlets. The eighteenth century is often rightly characterised as the age of the journal. The revolutionary fervour of the latter part of the century both accelerated the pace of change and radicalised the form of the newspaper, not always to the benefit of rational discourse. One of the most significant actions of the pro-French revolutionary ascendency in the Netherlands was Jean Luzac's forced resignation from the Gazette de Leyde, the axiomatic Enlightenment newspaper. ${ }^{43}$ In these strange new times, its cool rationality was prima facie evidence of counter-revolutionary tendencies. The complexities and contradictions of the search for an Enlightenment culture of news in some respects encapsulate very neatly the essence of a society in which political ambition, commercial considerations and human nature often combined to subvert the optimistically proclaimed spirit of the age. But then, reporting the news will always hold up an unflattering mirror to the face of the society it serves.

43 Popkin, News and Politics, pp. 188-214. 